\title{
Rozhovor s Janou Nechutovou a Janem Zouharem
}

Interview with Jana Nechutová and Jan Zouhar

Josef Petrželka

Byl jsem velmi potěšen, že pozvání ke druhému rozhovoru pro Studia philosophica přijali prof. Jana Nechutová z Ústavu klasických studií a prof. Jan Zouhar z naší katedry. Položil jsem jim podobné otázky jako kolegům v prvním rozhovo$\mathrm{ru},{ }^{1}$ tedy především otázky na jejich vztah k filosofii a jejich pojetí, příp. hodnocení filosofie. Odpovědi opět plně uspokojily mou zvědavost, snad tomu bude stejně i u čtenářů.

Jana Nechutová (*1936) vystudovala na Filozofické ${ }^{2}$ fakultě MU latinu a řečtinu. Od r. 1961 působí na Ústavu klasických studií, v letech 1995-1998 byla děkankou Filozofické fakulty MU. K jejím významným badatelským tématům patří mj. literatura české reformace a postava Jana Husa, k filosofickému bádání přispěla překlady děl Aurelia Augustina a Pierra Abélarda.

Jan Zouhar (*1949) vystudoval na téže fakultě češtinu a filosofii, krátce působil jako středoškolský učitel, pak v Ústavu pro výzkum společenského vědomí a vědeckého ateismu ČSAV a od r. 1988 působí na Katedře filozofie FF MU. Věnoval se mj. filosofii společnosti, ale jeho hlav-

1 Viz Studia philosophica. 2019, 66(1), s. 125-138. Rozhovor opět proběhl „živě“, byl z něj pořízen zvukový záznam, který byl následně za pomoci ještě ne zcela dokonalé umělé inteligence zpracován do předkládané podoby.

2 Slovo „filosofie“ a slova odvozená píšu jako antikář s „s“, pouze v oficiálních názvech a označeních (katedry, fakulty...) respektuji případné „z“. ním tématem jsou dějiny moderní české filosofie. ${ }^{3}$

\section{Jaký je váš vztah k filosofii?}

Josef Petrželka (P): Děkuji, že jste oba souhlasili s rozhovorem. Připravil jsem si otázky, které jsou hodně podobné těm v rozhovoru předchozím, ale přece jen jsou některé odlišné. A protože vy jste, paní profesorko, z jiné katedry nebo z jiného ústavu, mám pro vás $\mathrm{v}$ několika málo případech připravenu jinou otázku než pro Honzu a někdy otázku, která je trochu jinak formulována. Jinak jsou otázky stejné.

První otázka bude jedna $\mathrm{z}$ těch výjimek, ta bude jenom pro vás. Jaký je váš vztah k filosofii, paní profesorko?

Jana Nechutová (N): Na to se dá odpovědět velmi stručně, téměř jednoslovně, ale přece jenom bych to asi trošku rozvedla. Můj vztah k filosofii se rodil dlouho. Asi mně taky ještě položíte otázku, jak jsem se $\mathrm{k}$ ní dostala...

P: Ano.

$\mathrm{N}$ : ... takže s tím počkáme. Vyvíjel se v několika - řekla bych - přímo historických vrstvách, od rodinného prostředí přes prostředí všelijakých knihoven, přes

3 Podrobnější údaje o obou respondentech viz GABRIEL, Jiří - ZOUHAR, Jan - PAVLINCOVÁ, Helena - KROB, Josef (eds.). Slownik českých filosofir. Brno: Masarykova univerzita 1998. On-line verze viz <https://filozofie.phil.muni.cz/ vyzkum/publikace/scf>. 
církevní prostředí, přes můj kontakt s antikou a posléze $\mathrm{z}$ mého vřelého vztahu ke kolegům z filosofie, obyvatelům zdejšího ústavu. A tak se to hromadilo a vznikl z toho vztah k filosofii velmi těsný, ovšem těsný velmi subjektivně, protože na něco více než jenom na subjektivní vztah naprosto nemám ani pomyšlení, ani žádný nárok vzhledem $\mathrm{k}$ tomu, že o filosofii toho velmi málo vím. Je to tedy takový spíše obdivný vztah. Vřelý a obdivný.

\section{Jak jste se dostali $k$ filosofii?}

P: Děkuji. A vlastně jste se dotkla i té druhé otázky, totiž jak jste se $\mathrm{k}$ filosofii dostala. To už je otázka pro oba. Chcete $\mathrm{k}$ tomu ještě něco doplnit, nebo už to bude jenom na Honzu?

$\mathrm{N}$ : Já k tomu budu chtít něco doplnit, ale poněvadž jsem doted' mluvila, tak mne nechte odpočinout, já na to odpovím potom.

Jan Zouhar (Z): Já jsem se k filosofii dostával, bych řekl, víceméně náhodně. Na střední školu jsem chodil na stavební průmyslovku a tam jsem měl úžasnou paní profesorku z češtiny, paní profesorku Hanu Zlatuškovou, která mě do češtiny, hlavně do literatury, dost, abych tak řekl, pobláznila. Byla to druhá polovina šedesátých let, kdy se brněnský kulturní život víceméně odvíjel od významného časopisu, který se jmenoval Host do domu. A to jsme četli a já kromě toho, že jsem maloval všelijaké projekty a počítal stropy a vazníky, tak jsem se hluboce nořil, když to řeknu obrazně, do české literatury.

Když jsem odmaturoval, byl rok šedesát osm a já jsem se přihlásil na Filozofickou fakultu. Taky jsem se přihlásil na Sta- vební fakultu. Tam jsem dokonce byl taky přijat. Ale byl jsem přijat i sem. A ted' k té filosofii. Co si k té češtině vzít? Já jsem neměl gymnaziální průpravu v cizích jazycích ani v historii, protože my jsme na té průmyslovce měli historii myslím dva roky, nebo dokonce jenom jeden rok. Tak jsem přemýšlel, co k tomu, a tehdy mi paní profesorka Zlatušková poradila: „Vem si k tomu filosofii. Je tam dobrá katedra na té Filozofické fakultě."

Když nám pak tady v posluchárně číslo osm $^{4}$ začaly přednášky, cítil jsem se naprosto méněcenný. Na chodbě u posluchárny byly takové popelníky a vždycky, když byla přestávka, si tam studenti zapálili a ted' si vyprávěli Sartra, existencialismus, odcizení - to já jsem vůbec netušil, že takové věci existují! A tak jsem se tedy opravdu cítil takový méněcenný. Potom jsem přišel na to, jak se tady dá s těmi vlky výti.

Já jsem se vlastně k filosofii dostal zásluhou profesora Jaromíra Bartoše. Profesor Bartoš byl taková zvláštní postava. On nebyl na Katedře dějin filosofie a logiky, ale byl na té druhé katedře, která tady byla -

$\mathrm{N}$ : Metodologie.

Z: A to byla Katedra filosofie a metodologie věd.

N: Ludvík Tošenovský.

Z: A tu vedl profesor Tošenovský, náš neoblíbený postrach Tošenovský, a ten Bartoš tam působil a učil nás ontologii.

A zadával nám referáty. No a tehdy v šedesátých letech se objevila postava, která se potom stala jedním z představitelů undergroundu a která potom používala jméno

4 Pro mladší čtenáře - jedná se o současnou učebnu A11, která je ovšem nyní po rekonstrukci větší a modernější než bývalá „osmička“. 
Egon Bondy. Ale tehdy v těch šedesátých letech ještě pod svým jménem původním Zbyněk Fišer vydal dvě knížky. Jedna se jmenovala Otázky bytí a existence a druhá se jmenovala Útěcha $z$ ontologie. A to byly dvě knížky, které nám Bartoš zadal jako referát. Byli jsme tři, kteří jsme ty referáty dostali. A nějak se nám ty referáty povedly, načež si nás profesor Bartoš zavolal a sdělil nám svým hlubokým hlasem: „Kolegové, rozho$\mathrm{dl}$ jsem se vám nabídnout, abyste u mne psali diplomové práce.“

My jsme ztuhli, mysleli jsme si, že budeme psát diplomové práce na češtině jako na hlavním oboru. Tak jsme mu řekli, že si to musíme rozmyslet. A šli jsme k Čápovi. A tam jsme si to rozmysleli velmi rychle. Když nám profesor nabídl, abychom u něj psali diplomové práce, tak se to ani nedá odmítnout. Měli jsme týden na rozmyšlenou, za týden jsme se tedy zase dostavili, dostali jsme kávičku a sdělili jsme panu profesorovi, že ano.

On se tehdy zajímal intenzivně o problém pokroku. Tak jsme dostali problém pokroku. Měštánek, to byl jeden z nás, dostal pojem pokroku ve francouzském osvícenství. Ivan Mynář, to byl druhý, dostal pojem pokroku u Kanta a já jsem dostal pojem pokroku u Hegela. A tak jsme na tom začali pracovat.

Jenomže se stala hrozná věc. Pan profesor Bartoš nám umřel. Umřel a tady ti ostatní nechtěli mít s tím pokrokem nic společného, a tak nám nabídli různá jiná témata. Měštánek ještě chytl téma z české filosofie a nás s Ivanem Mynářem Cetl strčil do tehdejší sovětské filosofie. A tak jsme to studium dokončili.

A když to skončilo, tak jsme se odebrali každý někam jinam a šli jsme učit. Já jsem naplnil svůj sen a stal jsem se středoškolským profesorem češtiny a občanské nauky na Gymnáziu Slovanské náměstí. To bylo úžasné.

Ale zapomněl jsem říci ještě jednu věc. Bartoš totiž v Brně založil Kabinet pro filozofii jako pracoviště Akademie věd a zamýšlel to jako pracoviště pro dějiny filosofických pojmů. Jenomže do toho vstoupila normalizace a z Kabinetu pro filozofii se udělal Ústav vědeckého ateismu.

Takže bych řekl, že k filosofii jsem se dostal vysloveně náhodou a víceméně podfukem.

$\mathrm{N}$ : Já jsem se k filosofii dostala v daleko ranějších letech než Honza, protože jsem měla velmi osvícenou maminku, která se mnou a s mou mladší sestrou chodila do Wilsoňáku a kromě toho, že nás učila poznávat ptáky a všelijaké kytky a tak, také si tam předčítala, sama pro sebe a někdy i pro nás. Jednak Also sprach Zarathustra a jednak Pascalovy Myšlenky. To byla moje první setkání s filosofií. A potom jsem si nějak, asi z vlastního zájmu, vytáhla z knihovny první svazek Drtinových dějin filosofie. ${ }^{5}$ A já jsem to přečetla - to mně mohlo být takových, no možná patnáct -, a byla jsem naprosto fascinována tím, že se přede mnou otvírá svět, o němž jsem do té chvíle vlastně věděla jen to, že je nějaký Nietzsche a poprrípadě Pascal.

A pak jsem nějak asi maminčiným návodem došla $\mathrm{k}$ ještě jiné velmi zajímavé publikaci a to byl Neffův filosofický slovník zvaný tuším Antigorgias ${ }^{6}$ -

5 DRTINA, František. Myšlenkový vývoj evropského lidstva. 1902; později jako Úvod do filosofie - I. 1914, 1929, II. 1926, 1948 (pozn. red.).

6 NEFF, Vladimír. Filosofický slovnik pro samouky neboli Antigorgias. 1. vyd. 1948 (pozn. red.). 


\section{Z: Ano.}

N: - kde jsem se dozvěděla, že nic není, a i kdyby něco bylo - a tak dále, což je výrok, který mě fascinuje dodnes: Ač tedy věřím, že něco je, s tím poznáním a sdělením, to už je jinak. Do té míry přece jenom myslím alespoň trochu hlouběji, než by odpovídalo mé nedůstojné filologické profesi.

$\mathrm{Na}$ gymnáziu myslím jsem neměla možnost tohle nějak rozvinout, ale v těch raných vysokoškolských létech, což jsou léta podstatně dřívější, než jak svá vysokoškolská léta zde prezentoval a prožíval Honza, tak v těch raných vysokoškolských létech jsem se dostala do takového evangelického intelektuálského kruhu, kde jednak jel ten Sartre, ta Simone, a odcizení a ještě jiné pojmy, včetně tedy Heideggera, pro mne byly běžné, ovšem namnoze právě ani ne tak jako pojmy, spíše jenom jako výrazy, abych správně rozlišovala. Ale toto společenství mě uvedlo mimo jiné $\mathrm{k}$ brněnské, později tedy disentní, filosofce, velké učitelce, paní profesorce Komárkové.

Co bylo dál? Potom jsem se rozhodla studovat - tehdy se tomu snad ještě mohlo říkat klasická filologie. Ted' se sice také mluví o klasické filologii, ale domnívám se, že už jsme se do té míry odborně rozpadli do všelijakých drobnějších odborných segmentů, že už není klasického filologa, který by to jako ta generace před námi ještě obsáhl celé.

Nicméně naši učitelé ještě takoví byli. Byl tady profesor Novotný, kterého jsem ještě měla možnost chvíli přece jenom zažít, to byl ten autor velké čtyřsvazkové monografie o Platónovi a nepřekonaný překladatel veškerých Platónových dialogů.
A jak jsem na začátku tohoto rozkladu vzdala jakýsi hold své mamince, která mě prvně upozornila, že filosofie tady je, tak musím říct, že můj budoucí manžel Radislav Hošek nás učil antické filosofii, zkoušel mne a dostala jsem z toho jedničku. Ale neměla jsem na tom dosti a docházela jsem sem dolů. Tady - myslím, že to bylo přímo v těchto prostorách - sedával Jiří Cetl a ten učil mé dva kolegy, kteří byli v mém ročníku studenty oboru filosofie. Těm tady přednášel dějiny filosofie od Vorsokratiků až nevím kam.

A to bylo naprosto skvělé. To jsem si zapisovala a to jsem opravdu nasávala celou svojí bytostí. Nevím, jestli si z toho něco pamatuji. Rozhodně aspoň tu atmosféru a ta atmosféra byla umocněna tím, že Jiří Cetl u toho neustále kouřil a klepal popel do šuplíku svého stolu. A neměl nic proti tomu, abychom eventuálně kouřili i my, takže jsme se tu zcela filosoficky, dejme tomu, vznášeli v oblacích toho cigaretového dýmu.

A jak jsem se tak trošku nalepila na toho Jiřího Cetla a na Luboše Nového a tady na ten spolek těch takzvaných kluků, jak jsem vám o nich kdesi napsala, ${ }^{7}$ tak jsem se dostala mimo jiné do kontaktu s Robertem Kalivodou. A to byla ta chvíle, kdy jsem se jaksi společensky vzato tomu filosofickému okruhu přiblížila, spíše jsem mu osobně a soukromě a emočně propadla.

Když jsem se potom začala pod Robertovým vlivem a pod vlivem své evangelické výchovy věnovat české reformaci a speciálně Husovi - to už byla potom ta

7 NECHUTOVÁ, Jana. O klucích, filozofii, náboženství a ateismu, Studia philosophica, Brno: Masarykova univerzita, 2010 , roč. 57 , č. 1, s. 15-18. 
sedmdesátá léta - to jsem si potom trochu pletla, poněvadž jsem si myslela, že na cokoliv se ptáme z české reformace, že to všecko je filosofie. Samozřejmě to většinou filosofie nebyla.

Tím se dostávám k tomu tématu, které asi ještě nadejde, totiž jak je to s tím, co je označováno - vymyslel to Filip Melanchthon - jako philosophia christiana. Ale na to asi dojde.

Ještě to potom pokračovalo v tom smyslu, že jsem asistovala svému muži, když překládal Platónovu Ústavu a když překládal Festugièra Epikúros a jeho bohové.

To jsem se ještě dál dostala zase $\mathrm{k}$ jiným problémům spíše antické filosofie. Ale nikdy jsem do filosofie hlouběji nepronikla, a proto nemohu o sobě říct to, co o sobě nakonec vypověděl Honza, totiž jak jsem se stala filosofem. Já jsem se jím nestala.

Já jsem se pouze s filosofií setkávala, jak jsem se snažila takhle poněkud konfúzně popsat.

\section{Proč u filosofie setrváváte?}

P: Děkuji. Další otázka je spíš pro Honzu, protože se asi více týká právě té institucionální roviny: Když už jste se k filosofii nějakým způsobem dostali, tak jste si potom mohli bud' říct „no, tak to už nikdy víc“, anebo u ní zůstat. Honza u ní zůstává i na té institucionální rovině pěkně dlouho, tak se ptám proč. Co tě na filosofii natolik zaujalo, že jsi pořád tady?

Z: Já jsem k filosofii od počátku, když jsem se jí začal živit, přistupoval víceméně jako k cestě, jak odhalit nebo poznat atmosféru určité doby. K tomuto pojetí jsem se dostal právě i prostřednictvím toho vztahu k literatuře. Moje první texty v časopisech se věnovaly tomu, jakým způsobem určité myšlenkové útvary ovlivňovaly krásnou literaturu. Moje první velká studie se jmenovala Náboženstvi a česká dekadence. ${ }^{8}$ Já jsem tam sledoval, jak naši dekadenti Arnošt Procházka, Jiří Karásek ze Lvovic a Karel Hlaváček přistupovali k fenoménu náboženství. Zkoumal jsem to na základě jejich textů. Do toho se pak samozřejmě promítají i další věci - sociální situace tehdejší české společnosti, místo těch autorů mezi jinými autory. A tento vztah mezi myšlenkovou atmosférou doby a nějakými literárními produkty se ještě víc prohloubil v mé druhé studii, která se jmenuje Proměny Nietzschova vlivu v české kultuře na přelomu 19. a 20. stoleti. $^{9}$ To byly první texty, které jsem publikoval, a tady toto naladění - zkoumat místo filosofie $\mathrm{v}$ nějakých útvarech duchovní kultury a v celkové atmosféře doby - mi víceméně zůstalo na dlouhá léta.

\section{Co je filosofie?}

P: Děkuji. To byly takové úvodní a takové osobnější otázky

N: Vykládáme tak dlouho a pořád jsou to úvodní otázky.

P: Ale bylo to velice zajímavé a už ted' jsem spokojený s tím, co jsem se dozvěděl. Ted' přijdou otázky, které už jsou přece jen obecnější, a já jsem neméně zvědav, co se dozvím. První z nich je jednoduchá: Co je podle vás filosofie? Nebo co je filosofie pro vás?

$\begin{array}{ll}8 & 1977 \text { (pozn. red.). } \\ 9 & \text { Opět } 1977 \text { (pozn. red.). }\end{array}$


N: Filosofie hledá odpovědi na zcela základní otázky lidské existence, na základní existenciální otázky. Proč je tady svět, jak se tady ten svět vzal, co člověk na tom světě má pohledávat, jak se sem dostal a - přesahuje ho něco, nebo ne?

To si myslím, že je filosofie, to jsou otázky, ke kterým jsem se celkem brzy dostala, ale na které jsem si ve filosofickém ohledu vlastně nikdy neformulovala nějaké odpovědi. A proto, že mě tohle vždycky vzrušovalo, právě proto jsem se vždycky snažila se kolem ní ometat. To je pro mě filosofie.

Z: Já jsem dospěl k takovému názoru, že filosofie je hledání smyslu světa pro člověka, že nejde o smysl jen tak, ale o smysl věcí a celého toho okolí pro nás, pro člověka. Já jsem narazil na formulaci, již použil Erazim Kohák. On taky vychází z toho, že filosofie je hledání smyslu světa pro člověka, a současně to doplňuje větou, že smysl je to, jak se to všechno rýmuje.

My se snažíme věci, které nás obklopují nebo se kterými vcházíme do styku, vřadit do toho, co už víme, co je nám už blízké. To je ten smysl, který jsme už předtím v nějakých jevech postihli, a my se snažíme ty nové poznatky do toho vřadit tak, aby se to rýmovalo. To znamená, že filosofický pohled na svět by měl být nějakým způsobem konzistentní, měl by být ucelený, neměly by se v něm objevovat nějaké vnitřní rozpory, je to víceméně podrobeno požadavku konzistence či koherence.

N: Já si myslím, že naše výpovědi se celkem shodnou. Řekla-li jsem, že je to hledání, že filosofie se pokouší zodpovědět základní otázky lidské existence, tak je to vlastně to, co jste řekl vy. Ale s tou kohe- rencí, to je zajímavé, to pro mě jako pro nefilosofa sice samozřejmě není naprosto nové, ale znova mne to zaujalo, protože co si my s tou filosofií, se svým životem, $\mathrm{s}$ úvahami o něm počneme, aby to opravdu nemělo nikde žádné díry. To si myslím, že je to hrozně náročný požadavek.

\section{Je pro vás filosofie užitečná v osobním ži- votě?}

P: Děkuji za doplnění, protože jsem právě uvažoval o otázce, jestli se mi to jenom zdá, že vaše odpovědi, přestože jsou formulovány trochu jinými slovy, k sobě mají velmi blízko. Děkuji, že jste mi to sama potvrdila.

Když je filosofie tohle, tak rozhodně to je něco velice abstraktního, ale zároveň to $\mathrm{v}$ popisu vás obou bylo něco hodně lidského. Další otázka se proto ptá na to, jestli je pro vás takto chápaná filosofie užitečná v osobním životě, jestli to není jenom nějaká velká teorie, nýbrž jestli to může být prospěšné člověku v každodenním životě.

N: Já jsem poněkud specifický případ, protože před sebou máte živou praktikující evangeličku, takže ono je dosti obtížné říct, že je to právě filosofie, která mě v životě vede. Nepochybně je to různě filosoficky uchopovaný náboženský postoj k životu a ke světu. To je ta philosophia christiana melanchthonovsko-lutherovská, která mi zasahuje do života, která mne životem vede a řídí, takže - takže ano.

Ale byla bych neupřímná, že je to ausgerechnet filosofie. Není. Je to ta philosophia christiana, což samozřejmě je útvar složený z náboženského a filosofického prvku, a jak tady povídali posledně kolegové, 
někdy ten útvar těžko drží pohromadě. Ale musí se s tím nějak vyjít.

Z: Já bych nemohl říct, že můj život je nějakým způsobem ovlivňován filosofií. A snad bych to řekl tak, že jsem vlastně nedospěl k tomu, že bych si zformuloval nějakou svou řekněme životní filosofii. Přestože učím tolik let dějiny filosofie, tak jsem tam pro sebe nenašel - to musím říct naprosto upřímně - nějaký takový model, který by mě uspokojil jako životavodič. Nenašel jsem, ani jsem nehledal. Můj vztah k životu není ovlivněn nějakou odbornou filosofickou teorii nebo nějakým odborným filosofickým názorem a je veden spíše takovou tou životní filosofií, když to tak nazvu, přirozeným vztahem ke světu, k lidem, který jsem si osvojil na základě výchovy v dětství a na základě kontaktu se světem. V základech mého názoru na svět je taky křestanský pohled, protože já jsem jako chlapec vyrůstal v katolické rodině a chodil jsem do náboženství, dokonce jsem i ministroval v kostele v Husovicích. Ovšem já jsem se s náboženstvím jaksi tiše a přirozeně v určité fázi, zhruba kolem desíti, jedenácti let, rozešel.

Ale chci tím říct, že v té mé životní filosofii je nesporně tento křestanský základ obsažen. Potom jsem však přešel spíš na takovou pozici nějakého pragmatického vztahu ke světu.

$\mathrm{N}$ : Z toho se totiž nevyzujeme, jsouce Evropani, protože to křestanství je opravdu v základech kultury. Je to analogické k situaci prvních velkých křestanských otců, autorů at řeckých nebo latinských. Co my máme s tím křestanstvím, že mnoho vzdělanců není ochotno to přijmout, tak ti první křestanští autoři se zase strašně distancovali od antiky - a nešlo to a nešlo. Protože tak jako je do nás zakousnuté to křestanství, tak byla do nich zakousnuta antika. A tam vznikla úžasná fúze toho v podstatě judaismu a antické kultury, která se zakousla do každého Evropana.

P: Stejně jako v tom minulém rozhovoru, tak i ted' se to -

N: - cpe do toho náboženství. Když si povoláte praktikující evangeličku, tak se to dalo čekat.

\section{Co je přičinou napětí mezi filosofií a nábo- ženstvím?}

P: Tak to se nemůžu na to náboženství nezeptat. A když to zatím u vás obou vypadalo, jako že filosofie $\mathrm{s}$ náboženstvím jde spíše dohromady, tak já trochu provokativně poukážu na to, že mezi filosofií a náboženstvím byly velké třenice. Jak byste tyhle třenice nebo tyhle střety, či naopak setkávání, jak to nazval Jirka Svoboda - jak byste je vysvětlili? Proč je tam často takové velké napětí?

N: Protože v náboženství je příliš mnoho iracionality, kterou poctivě uvažující filosof, racionálně uvažující filosof těžko přijímá. Já se domnívám, že nějakou odpověd' mám. A ta odpověd' zní tak, že oba ty prostory, jak ten náboženský, tak ten filosofický vypovídají o tomtéž, ale každý svým zcela specifickým jazykem. A za velký či hlavní rozdíl považuji to, že filosofie nemusí postulovat transcendenci.

Já jsem v roce 2011 pronesla příspěvek, který jsem nazvala právě „Philosophia Christiana“, což jsem opsala od Erasma Rotterdamského. To bylo na evangelické teologické fakultě setkání $\mathrm{k}$ pětasedmdesátinám někdejšího děkana, mého 
dobrého přítele, pana profesora Filipiho. Odrazila jsem se od Colloquii familiarii Erasma Rotterdamského, kde to poslední kolokvium je tuším „Colloquium philosophorum"10, a tam právě Erasmus Rotterdamský ukazuje, jak je to o té jedné, téže věci a jak ta odpověd' se nakonec hlubinně vzato ani moc neliší.

Fakt je, že když si ty věci chci formulovat jazykem náboženství, musím rezignovat na racionální myšlení nebo na metody racionálního myšlení s vědomím, že jsou svéprávné a že odpovědi, které hledají, jsou platné, ale že vypovídají o těch základních skutečnostech jiným jazykem. Křestanství je mýtus jako každé náboženství. Ten mýtický jazyk a to, že prostě člověk vyjadřuje své základní postoje, odpovědi na základní otázky, že je formuluje v těch náboženských obrazech - to může být věřícímu člověku blízké a musí si být přitom vědom toho, že se nesápe na odpovědi v pravém slova smyslu filosofické.

Z: Já jsem už tady naznačil, že moje myšlenkové dospívání se odehrávalo v atmosféře šedesátých let. A tam docházelo k takové zvláštní a pozitivní situaci, totiž postupem času dokonce i formálně - k dialogu mezi křestany a nevěřícími, a právě ten dialog přinášel takové odpovědi nebo taková řešení, která byla schopna - ted' to možná přeženu - uspokojit obě strany.

N: To je velmi podobné jako to šestnácté století, Luther s Melanchthonem, dvojice naprosto nerozlučná a Melanchthon,

10 Colloquium philosophorum. In Opera omnia Desiderii Erasmi Rotterodami recognita et adnotatione critica instructa notisque illustrata, Ordinis primi tomus tertius (ed. L.-E. HALKIN, Amsterdam 1972). velký filosof - a on formuluje Augsburské vyznáni. ${ }^{11}$

Z: Právě v té době se u nás objevil dokonce brněnský autor, a to byl Vítězslav Gardavský, který zase udělal takový krok ne ke sblížení, ale vyjasnění těch pozic. Začal uveřejňovat na pokračování v Literárnich novinách práci, která potom vyšla knižně a proslavila ho, Bůh neni zcela $m r$ tev. ${ }^{12}$ A tam právě přemýšlí o tom, jestli náboženství ještě v moderním světě pro lidi něco znamená a co vlastně znamená $\mathrm{i}$ ateismus $\mathrm{v}$ tomto světě. A to jsme četli a to nás výrazně ovlivnilo.

A když vzpomenu na atmosféru tady na katedře, tak vedoucí katedry Lubomír Nový byl člověk, který vyšel z evangelického prostředí, a to v něm stále bylo. Když jsme diskutovali, on se neustále odvolával na náboženskou evangelickou zkušenost a v mých očích to vždycky byl člověk, který, ačkoliv tedy byl marxista, měl stále $\mathrm{k}$ náboženství nebo $\mathrm{k}$ náboženské víře osobní vztah.

N: Ta syntéza je zjevná i u některých osobností v současnosti, známe přece řadu myslitelů katolických a evangelických, kteří mohou být zařazeni stejně dobře do galerie filosofů jako do galerie teologů nebo prostě náboženských svědků. U katolíků vezměme třeba bratry Flosse, Karla i Pavla. Koneckonců Erazim Kohák, jak zde bylo řečeno -

Z: - Hejdánek -

N: Hejdánek, zcela nepochybně. Profesor Skalický, budějovický, který dlouhá

11 Viz Augsburské vyznáni. Překlad Petra ČERNÁ. Český Těšín: Sdružení Martina Luthera v ČR 2010.

12 GARDAVSKÝ, Vítězslav. Bůh neni zcela mrtev. Praha: Československý spisovatel 1967. 
léta žil ve Vatikánu a myslím, že měl velmi blízko k Janu Pavlu II. To je rovněž výsostný teolog s obrovským filosofickým vzděláním i s formací filosofickou.

P: Takže i když jsem tu otázku formuloval záměrně tak trošku provokativně, vlastně jste se oba snažili spíš poukázat na nějaké spojení nebo na to, co mohou filosofie a náboženství dělat dohromady.

$\mathrm{N}$ : I co do metodologie - třeba $\mathrm{v}$ ontologii, metafyzice je, myslím si, zcela evidentní, že filosof i teolog musí používat obdobných nástrojů.

\section{Je důležitější v životě filosofie, nebo nábo- ženství?}

$\mathrm{P}: \mathrm{V}$ tom př́padě poněkud pozměním další připravenou otázku. Ta totiž navazuje na dř́ivější otázku, nakolik je to pro vás filosofie užitečná v osobním životě. Když se nám tam dostalo to náboženství, zkusím ji formulovat zase tak trošku provokativně. Je podle vás pro každého člověka nebo pro přemýšlivého, „teoretického“ člověka v tom aristotelském slova smyslu nebo pro toho profesionálního filosofa důležitější filosofie, nebo náboženství? Nebo zase nějak dohromady?

$\mathrm{N}$ : Jak u koho. To zase záleží na vnitřní výbavě toho člověka, na jeho genetické výbavě, na tom, s kým se setkal ve velmi raném věku. Myslím, že se otázka těžko může takhle postavit, jestli je důležitější jedno, či druhé. Opravdu jsem přesvědčená, že je to individuální.

Z: Ano. A ještě bych řekl, že když odmyslíme ty profesionální filosofy nebo teology a budeme se věnovat normálním vzdělaným lidem, tak u nich často zjištuji, že oni ty postoje náboženské a nenábo- ženské vlastně ani tak od sebe neodlišují.

$\mathrm{N}$ : To vidíte na mně.

Z: Mám přátele, některé kamarády ještě z dětství, kteří jsou třeba akademičtí malî́i a věnují se umění, a oni jsou rádi, když s nimi někdy rozprávím tady o těch věcech. Ale když jim začnu ř́kat, že toto je filosofie a toto je náboženský pohled na svět, oni mě napadají a říkají, že v tom není přece žádný rozdíl, že oběma těm názorům jde o totéž, jde o to, aby se člověk v tom světě vyznal, aby měl nějaké zásady, kterými se bude řídit. A existence či neexistence transcendentní bytosti, ta je pro ně v tom případě úplně nedůležitá.

Když jsem se začal věnovat Masarykovi, tak mě zarazilo, že on mluví neustále o tom, že náš názor na svět musí být vědecký, a současně jedním dechem mluví o sub specie aeternitatis a o hledisku věčnosti a je hluboce nábožensky věřící člověk. A když jsme mluvili o tom mýtu, tak Masaryk se domnívá, že ted' nastává konečně doba, kdy mýtus bude nahrazen vědou, že skončí všelijaké ty vymyšlenosti, které s sebou nese ten mýtický pohled na svět, a bude věda. A chce dělat náboženství vědecké, což, když se nad tím člověk zamyslí - jak? Jak to chce dělat? Jak chce dokázat některé základní pravdy náboženské nauky? Vědecky?

$\mathrm{N}$ : Vy Masaryka velmi dobře znáte opravdu on to takhle bral?

Z: Ano, on ř́kal, že chyba nastala, když se od sebe ty dvě věci oddělily, víra a věda, a že člověk přestává věřit víře a nerozumí vědě, a proto je velmi náchylný řešit svou situaci krizově, to znamená vražda nebo sebevražda. A když si to člověk přečte, tak si ř́ká - co to je? Náboženství má být vědecké? Má být opřeno o vědu? Jak si to 
on představuje? Nepřišel jsem na to, jak si to představuje.

$\mathrm{N}$ : Mluvíme o tom, že mezi těmito dvěma oblastmi nepochybně spojení je, jednak kladením těch otázek, svým způsobem i odpověd'mi, ke kterým dospívají oba ty myšlenkové prostory, nicméně ta řeč je jiná. A myslím, že ta řeč je naprosto podstatná. I když to vypadá jako něco jenom instrumentálního, ona ta řeč není úplně jenom instrumentální.

\section{Jaký je nebo měl by být význam katedry fi- losofie pro fakultu?}

\section{Jaký je smysl či význam studia filosofie pro společnost?}

P: Děkuju. Já se zase vrátím na katedru, na fakultu a budu mít tu otázku, která bude možná trochu jinak formulována pro vás, paní profesorko, a trochu jinak pro Honzu. Jaký je nebo měl by být význam katedry filosofie pro fakultu, případně pro univerzitu? To je formulace pro vás a pro Honzu v takové provokativní podobě: Proč mají existovat katedry filosofie a být placeny ze státního rozpočtu? Jaký je smysl či význam studia filosofie pro společnost?

N: Já bych se spíš vrhla na tu otázku, kterou jste položil Honzovi.

P: To samožrejmě můžete, jak chcete.

N: Ten filosof na tom vždycky byl a vždycky bude - at̉ už bude placen z jakýchkoli rozpočtů - oproti jiným oborům mizerně, takže on toho z toho státního rozpočtu zase tolik nevyčerpává. Já bych tady citovala dvojverší, které vzápětí přeložím: Dat Galenus opes, dat Iustinianus honores, pauper Aristoteles cogitur ire pede, což moc pěkně přeložil Mertlík. Už nevím, jak přeložil to, že ten Galenus, doktor si vydělá prachy a že ten právník, Justiniánus, si užívá slávy, ale pak to Mertlík překládá „filosof pěšky se vleče, chudý jak kostelní myš“. Tolik co se týče státního rozpočtu a našeho sahání po grantech.

Ještě ta otázka, která byla adresována mně. Je to strašně subjektivní, nevím, je-li tahle odpověd' racionální nebo jestli v tom jsou především moje emoce anebo nějaké prapodivné předporozumění. Já se domnívám, že jsou tři obory, kterých je třeba v každé společnosti a které stojí v čele humanitních věd a na které každé odvětví věd humanitních vždy narazí a se kterými se musí vyrovnat, at už metodami a nástroji anebo svým obsahem, svými základními tezemi. A to je teologie, je to filosofie a je to s prominutím bývalá klasická filologie, která doplňovala tyto dva obory nebo jim dávala další dimenzi a to tu, že odkazovala $\mathrm{k}$ antickému základu. Bez těchto tří disciplín je ten celý vědecký nebo kulturní prostor - jako když řekl Konstantin filosof, že národy bez knih jsou nahé - tak je kulturní prostor nahý bez těchto tří oborů. Takže financovat. Pokud možno tučněji.

Z: Já ř́íkávám studentům: Když Herbart sdělil své mamince, že bude studovat filosofii, maminka se zhrozila a na svého syna volala „Philosophie gibt kein Brot!“ a radila mu, aby se na to vykašlal a šel studovat něco jiného.

N: Teologii, že by mohl být prelátem.

Z: Herbart se prosadil a stal se profesorem a jistě netrpěl nouzí. Ale je to tak, že vlastně být absolventem filosofie, jenom filosofie, nepřináší nějakou dobrou startovní pozici pro praktický život. Ale my 
známe naše absolventy, kteří se prosadili, ačkoliv část $\mathrm{z}$ nich studovala jenom filosofii, protože se tady naučili komunikovat, argumentovat.

Ale samozřejmě ta tvoje otázka je širší. Má cenu, aby filosofové byli nějak institucionálně zakotveni na vysokých školách? Já si myslím, že to je otázka, kterou si každá společnost musí položit: Vyplatí se jí mít kultivované inženýry, kultivované lékaře, kultivované přírodozpytce - filosofie totiž nesporně přispěje k jejich kultivaci? Anebo mít prostě stavební inženýry, kteří nebudou vidět dál než na konec nějakého toho nosníku? Co je pro společnost výhodnějšî́? Mít filosofy na vysokoškolských institucích, kteří budou nějak zapojeni do vzdělávání studentů, anebo ne? Já si vzpomínám na dobu těsně po listopadu, kdy se najednou objevila - nikdo to nevyvolával - potřeba některých vysokých škol v Brně, aby tam přednášeli filosofové. Např́íklad dnešní Mendelova univerzita, dříve Vysoká škola zemědělská -

$\mathrm{N}$ : A ten Klapetek, že?

Z: Ano. A oni prostě najednou žádali, abychom tam šli do jejich kurzo̊ přednášet. Ono to opadlo, dneska už to takhle není. Nám se podařilo udržet určité hodiny na přírodovědecké fakultě, ale už ne na té lékařské, jak tady paní profesorka zmínila toho Klapetka.

Já si vzpomínám na jednu takovou příhodu. Existoval profesor, který se jmenoval Igor Zhoř. Byl to malír a teoretik umění, který byl v devadesátých letech na pedagogické fakultě. A on tam postupně budoval obor a katedru a přišel na to, že by bylo dobré, aby tam měl doktorské studium. A ted' někde vyhrabal, že součástí studijního plánu doktorského studia by měla být filosofie. Pan profesor Zhoř přišel za mnou (tenkrát jsem byl vedoucím katedry) a řekl: Prosím vás, já bych měl takovou prosbu, já bych potřeboval, kdybyste $\mathrm{v}$ rámci doktorského studia na pedagogické fakultě vedl kurzy z filosofie. Tak jsem se podílel na Ph.D. absolventech pedagogické fakulty. Potom Zhoř odtamtud odešel a oni postupně přestali mít o filosofii zájem. Ne že by si tam vzali někoho z vlastních řad pedagogické fakulty, vůbec to vypustili z programu. A tady to taky tak cítíme.

N: No však právě!

\section{Jak pojmout výuku filosofie pro studenty nefilosofických oborů?}

P: Děkuji. Další otázka vlastně mírí vlastně také sem, jenom o stupeň níž. Filosofie jako společný základ - to je pro mě osobní otázka, protože sám to učím a sám pořád nemám úplně jasno, jak to učit a k čemu by to mělo být. Jak tedy pojmout kurz filosofie pro studenty jiných oborů? A zase je ta otázka na vás trochu z jiného pohledu. Od vás, paní profesorko, bych rád slyšel, co vy byste považovala za užitečné, aby se vaši studenti dozvěděli z filosofie. A ty, Honzo, máš s tímto kurzem dlouholeté zkušenosti - jak jsi to tedy pojímal nebo jak myslíš, že by bylo záhodno to pojmout? K čemu by ten kurz měl studentům nefilosofických oborů být?

Z: Já jsem měl vždycky za to, že to je dramaticky řečeno - poslední příležitost, aby se student naší fakulty něco dozvěděl o filosofii, protože je to Filozofická fakulta a z toho hlediska je to důležité. Ale původně, ještě za Luboše Nového, jsme měli takový plán, který se nám nepoda- 
řilo naplnit - že by to mělo být vždycky zaměřeno pro obor nebo skupinu oborů. Luboš měl před sebou pořád takovou vizi, že když kdysi dávno učil filosofii psychology, že ten kurz vedl speciálně pro ně a že tam vymýšlel všelijaké věci, které přesahovaly obecný rámec. Jenomže tehdy se to nepodařilo prosadit, že by prostě někdo měl třeba západní filology, někdo by měl historiky, někdo by měl češtináře. Nepodařilo se to z rozvrhových důvodů, protože nebylo možné nějak dát rozvrhově dohromady skupinu, která by byla oborově blízká a vyslat tam někoho, kdo by tam měl filosofii pro tu skupinu. To se nepodařilo.

Já se domnívám, že další cesta by měla být v tom, nějakým způsobem prohloubit přednášky z filosofie nad rámec všeobecných znalostí. Já ale nevím jak, to nevím.

$\mathrm{N}$ : To je jedna cesta, to znamená dejme tomu ty lingvisty vést $\mathrm{k}$ filosofii jazyka, jiné obory trochu jinak. Já nejsouc filosof a vidouc všechno zjednodušeně a méně poučeně - já bych všem napařila dějiny filosofie. At je lingvista, at je schöngeist, at je to jakýkoliv obor, tak myslím, že přehled o tom, jak různí lidé a různé směry řešili základní otázky lidské existence, to by myslím mohlo být velmi užitečné.

Z: Ano. Z té naší sestavy, která se na tom podílela a podílí, někteři šli tímto směrem. To byl třeba Jirka Svoboda. Ten tam přednášel dějiny filosofie, velmi oblíben u posluchačů, a taky požadavky ke zkoušce pak mohl jasně formulovat. Já jsem kdysi zvolil jinou cestu a sice problémové členění. Začal jsem ontologií a vyprávěl jsem tam jednotlivé ontologické modely, které se $\mathrm{v}$ dějinách filosofie objevily. Byla tam jména, byly tam kon- cepce. Neměl jsem s tím nikdy problémy z hlediska ukončení v testu. Potom byla epistemologie - co je pravda a poznatelnost a všechny ty věci. Takhle jsem to měl strukturováno.

Vylepšení by mohlo být jenom tím směrem, o kterém jsem mluvil. Ale otázka je, jestli by to vůbec něco přineslo. Kdyby třeba Jožka měl jenom klasické filology a vyprávěl jim o Platónovi a Aristotelovi, jestli by to pro ně bylo přínosnější, než aby slyšeli, jaké jsou teorie pravdy a co je to pragmatismus. Já nevím.

Jaký je váš vztah $\mathbf{k}$ české filosofii? Jaký je význam české filosofie? Jak by se měla česká filosofie učit?

P: Děkuji. Ted’ bychom přššli $\mathrm{k}$ české filosofii. To je zase téma, které vás oba spojuje, byt jste se věnovali každý jinému období české filosofie. Mám několik otázek, ale položím je všechny naráz, protože jsou spolu spjaty, a můžete si vybrat, jak na ně budete odpovídat. Jednak je to otázka opět na váš osobní vztah k české filosofii. Potom - jaký je význam české filosofie? Jaký je význam české filosofie nebo její vztah k dějinám světové filosofie? A jak by se měla česká filosofie učit? Nebo co může česká filosofie říct současným studentům?

N: Já se tady asi budu hodně držet zpátky, protože to je pro mne otázka velmi těžká. Já jsem se v dějinách českého myšlení vždycky soustředovala právě jenom na českou reformaci, a to nejsou dějiny filosofie. Takže to necháme Honzovi.

Z: Ta otázka je dost komplikovaná. Já se zabývám filosofií devatenáctého a dvacátého století. A tam pokud jde 
o českou filozofii, stojí na jedné straně názor Podivena ${ }^{13}$ - to jsou ti tři autoři, kteří se rozhodli pošpinit výkon našeho národa, a ti se vyjadřují o české filozofii na konci devatenáctého století nejenom s despektem, ale velmi pohrdlivě a v tom svém díle otevřeně říkají, že tady vlastně žádná filosofie nebyla a není, že to, co se vydává za filosofii, jsou v podstatě jakési amatérské pokusy něco formulovat, ale že to nejsou skutečně filosofické otázky ani filosofické odpovědi. Na jedné straně je tady tento názor a na druhé straně vlastně v tom v devatenáctém století je několik velkých jmen. Já neříkám, že jsou to představitelé české filosofie jako takové. Je tady Augustin Smetana, ještě před ním Bernard Bolzano. Ale - Bolzano nenapsal česky ani větu a Smetana myslím napsal česky jeden článek a jinak psali oba německy.

$\mathrm{N}$ : Ačkoli to neznamená, že to není česká filosofie.

Z: Ano, to je právě ten problém, co s těmi autory, kteř́i tady působili, ale nepoužívali češtinu jako komunikační prostředek.

A ted' přichází druhá polovina devatenáctého století a já to ted' vidím skutečně tak, že filosofie se tady musela určitým způsobem napřed vyklubat. To byl ten neštastný Durdík, o kterém se traduje, jaký to byl despota a krasovědec, ale Durdík udělal pro českou filosofii strašně moc.

A je tady Masaryk, který vlastně sám nechce být považován za filosofa, několikrát o sobě říká, že není filosof, že není metafyzik, že nechtěl budovat žádný filo-

13 PODIVEN. Češi v dějinách nové doby. 1991. Pod pseudonymem „Podiven“ se skrývá autorský kolektiv Petr Pithart, Petr Př́íhoda, Milan Otáhal. sofický systém. Ale stalo se, že filosofie je s Masarykem spojována. A za to může ne Masaryk, ale Čapek, který ty názory systematizoval a vytvořil jakousi matrici Masarykova filosofování.

Ve dvacátém století to začíná štastně neštastně těmi pozitivisty, ale potom v době první republiky si myslím, že filosofie tady už měla určitou vysokou úroveň. At’ už to byli Vorovka a Hoppe a ti iracionalisté na jedné straně anebo na straně druhé ti skladební filosofové, jako byl J. L. Fišer nebo třeba Innocenc Arnošt Bláha, který i když formálně je sociolog, hodně přispěl $\mathrm{k}$ rozvoji české filosofie.

A potom tady máme ten balvan a tím je Patočka. A to je velký interpretační problém. Jednak u nás existuje určitá skupina těch, kteří se vydávají za znalce Patočkova díla - většinou ještě chodili na jeho přednášky - a kteří jsou majitelé klíču k Patočkovi a dbají na to, aby nikdo na Patočkově památce nezkřivil žádný vlas. A potom je tady několik autorů, kteří - i když jsou velkými milovníky Patočky - programově říkají: Česká filosofie ano, ale bez Patočky. To je třeba Kohák. Když Kohák organizoval konferenci v Praze, ze které potom vyšla knížka, ${ }^{14}$ tak vyžadoval, aby nikdo nemluvil o Patočkovi. Bylo to věnováno současné filosofii - ale nemluvme o Patočkovi a mluvme o těch dalších, o J. L. Fischerovi, o Tvrdém a o Hoppovi a o Vorovkovi... On sám, který tak propagoval Patočku třeba ve Spojených stá-

14 České myšlení: česká filosofie a česká kritická teorie, 7. - 9. listopadu 2011. Příspěvky z konference shrnula kniha KOHÁK, Erazim - TRN$\mathrm{KA}$, Jakub (eds.). Hledáni české filosofie. Praha: Filosofia 2013. (Pozn. red.) 
tech, si uvědomil, jaká je to zátěž, jaký je to balvan v české filosofii a jak obtížně se s ním vyrovnává ta generace, která ho už nezažila, která ho zná jenom z knížek.

Já osobně si myslím, že Patočka, pokud jde o filosofii, přesáhl hranice tohoto národa, že to je skutečně evropská postava. A zasloužil se o to především jeho vztah k dějinám, to jsou Kaciřské eseje, které myslím jsou významným inovativním krokem. A druhá věc je pojetí přirozeného světa, kde on vlastně určitým způsobem předjímal to, $\mathrm{k}$ čemu došel Husserl až po něm. Problém přirozeného světa je druhý závažný problém, ke kterému $\mathrm{Pa}$ točka výrazně přispěl.

A co ta soudobá, opravdu ta dnešní filosofie u nás? Je tady spousta autorů, at̉ už na Filosofickém ústavu nebo na vysokých školách, kteří se věnují dějinám filosofie. A to je myslím záslužná činnost. Potom je tady velká skupina těch, kteří dělají filosofii jazyka. Jazyk a komunikace - to je téma, které od těch dvacátých, třicátých let minulého století zřejmě už zůstane vděčným tématem. A potom je tady obrovský balík problémů, které spadají do sociální a politické filosofie. V Praze na Filosofickém ústavu je kolektiv, který tomuto tématu věnuje zvýšenou pozornost, vede ho Marek Hrubec.

Viděl bych tu současnou českou filosofii na jednu stranu Patočka, Patočka, Patočka, druhá věc jsou ty dějiny filosofie, které se u nás dělají myslím zásluhou těch zasloužilých staříků, jako je Milan Sobotka a spol. A potom je tady ten jazyk a ta sociální filosofie. A na každém úseku jsou lidi, kteř́í jsou dobří.

Takže nevidím budoucnost české filosofie černě. Nespojuji to ted' s naším pracovištěm, ale myslím obecně, že když se ty zátěže - zátěž Patočka - nějakým zpo̊sobem překonají, tak myslím, že česká filosofie má šanci, aby se rozvinula.

\section{Jak učit českou filosofii?}

P: Já bych připomněl jednu z těch podotázek. Právě tobě bych tuto otázku rád položil, protože ty jsi učil českou filosofii s Helenou Pavlincovou dlouhá léta, možná spíš desetiletí. A já vím od studentů (a sám musím přiznat, že taky jsem se na to tak díval), že přece jenom ta česká filosofie působí jako takový nějaký chudý příbuzný dějin světové filosofie nebo evropské. Jak to tedy učit, aby to studenti měli rádi a aby to pro ně bylo zajímavé? Je u české filosofie možný nějaký jiný přístup než k dějinám filosofie obecně nebo $\mathrm{k}$ filosofickým problémům obecně?

Z: Já bych se ted' odvolal na svoji knížku Minulý konec stoleti. ${ }^{15}$ Ta knížka je věnována české filosofii přelomu devatenáctého a dvacátého století. Filosofie tam je, je tam Masaryk. Ale není tam jen filosofie, je tam Machar a Gabriela Preissová a další. Jde tam především o to, jaká byla myšlenková atmosféra té doby. Co to bylo za dobu? A já si myslím, že takhle je možno přistupovat $\mathrm{k}$ dějinám českého myšlení. Nevyzdvihoval bych nutně filosofii jako základ tohoto př́ístupu. Myšlení jak to myšlení vypadalo, jakým zposobem se promítalo do každodennosti, co se dostalo k lidem prostřednictvím tehdejších médií nebo tehdejších možností šíríit poznatky nebo teorie.

Z r. 2000 (pozn. red.). 
Krásným př́ikladem toho, co v těch osmdesátých letech 19. století hrálo velkou roli v pražském intelektuálním životě, byl Americký klub dam, který zorganizoval Vojta Náprstek. Když se na to díváte - Durdík tam měl přednášku, jednu, druhou. Masaryk? Nemohl odmítnout pozvání, když měl manželku Američanku a Americký klub dam - tak se tam vypravil. Odborný dopad těch přednášek byl mizivý, ale u těch, co tam byli, to muselo zanechat nějaké stopy. A toto mě vždycky nejvíc zajímalo, jak to myšlení, abych tak řekl, fungovalo v oběhu, jak se k němu různí lidé vyjadřovali a jak ho přijímali, nebo odmítali.

Jedině takhle vykládat českou filosofii nebo české myšlení, aby to bylo zajímavější, opírat to o nějaké historické události nebo povědomí o těch historických událostech, protože to podvědomí o minulosti je u studentů velmi chabé.

N: Já si stejně myslím - a vy jste to ted' velmi zdůraznil -, i když k tomu přistupuji úplně z jiného konce, že to devatenácté století bylo velmi plodné co do základů dalšśho vývoje kultury, především druhá polovina devatenáctého století, tohle by se mělo v dějepise učit, o dvacátém století nemluvě. Takže jsem velmi ráda, že mi to s tím devatenáctým stoletím potvrzujete.

Z: A myslím, že i naši historici to takhle vnímají, protože tam se taky zrodily základy toho, jak společnost funguje dodnes. A ta filosofie - i když na jedné straně ten Podiven tam nenajde nikde ani chlup, tak na druhé straně je tam to, co napsala Jiřina Popelová: Ano, jsou tady dlouhá období, kdy jako by v Čechách žádná filosofie neexistovala. Ale ř́ká Popelová, já to budu parafrázovat - každá doba má nějaký filosofický potenciál. On nemusí být vyjádřen ve filosofii, on může být vyjádřen v krásné literatuře. On může být vyjádřen ve vědě, on může být vyjádřen v hudbě. Čili Popelová jako by to vnímala tak, že každá doba je prostě nějak filosoficky těhotná, ale může to - když je filosofie slabá nebo o ni nikdo nestojí - být vyjádřeno i v jiných formách a krásná literatura se $\mathrm{k}$ tomu nabízí. I ten Masaryk postavil své práce na krásné literatuře.

\section{Jaká je brněnská Katedra filozofie?}

P: Děkuji. Poslední otázka. Má tato katedra něco, co by šlo označit jako její speciální génius, duch? Je tady nějaký rukopis nebo je tady něco, čím by se tato katedra lišila od jiných kateder filozofie? A zase paní profesorka se na to může podívat z vnějšku, což je pro mě o to zajímavější, Honza zase zevnitř na základě dlouholetých zkušeností.

N: To já nemohu než opakovat to, co už zde bylo mnohokrát řečeno. A musím ten dotaz i tu odpověd' rozšíríit. Ta katedra je nezastupitelná právě tím, čím se zabývá, a bez filosofického základu nejsou humanitní vědy nikde ukotveny. Já znám málo současnou podobu Katedry filozofie, ale nemohu, nechci si vůbec představit, že by mohla existovat filozofická fakulta, na které se tahle specifická a výsostná humanitní věda nepěstuje a netvoří jakýsi základ pro všechno ostatní. Kam se můžeme utíkat, kam se můžeme chodit ptát? Asi to málo děláme. Tehdy v těch šedesátých letech jsme to dělali.

Nějak jsme k sobě měli v těch šedesátých, sedmdesátých letech v rámci celé 
fakulty blíž asi i fyzicky a fakt je, že jsme byli daleko provázanější a že jsme se chodili ptát filosofư, chodili jsme se ptát taky muzikologů, chodili jsme se ptát taky pana profesora Kutala anebo Richtera čili historiků umění. Ale tvrdím, že filozofickou fakultu, na níž by nebyla tahle možnost - soustředit se na ty základní otázky a očekávat jakési odpovědi, si nechci vůbec představit. Do jaké míry současná Katedra filozofie naplňuje tohle řekla bych zadání nebo do jaké míry té představě odpovídá, to upřímně řečeno právě při té současné roztř́šstěnosti našich oborů nějak exaktně nevím.

Z: Já si myslím, že tato Katedra filozofie měla svého času skutečně výrazný vnitřní duch. Já to pamatuji ještě jako student. A pamatuji, že když srovnám ty dva obory, které jsem studoval - češtinu a filosofii, tak na češtině jsme byli vnímáni jako kusy na pásové výrobě. Tam bylo několik lidí, kteří měli chut se se studenty normálně bavit a dělat normálně takovou prrirozenou srandu. To byl třeba Lamprecht, který nevynechal jedinou příležitost, aby s námi nepromluvil a neřekl nám nějaký žertovný příběh z minulosti. Na literatuře byl vynikající Karel Palas, to byl skvělý muž.

Ale tady to bylo jiné. Tady byl skutečně ten duch katedry, tady člověk mohl přijít, a když měl nějaký problém, tak oni měli prostě radost, že s námi mohou povykládat, jezdit s námi na exkurze. To všechno Katedra filozofie splňovala. Já nevím, jak je to ted', je tady jakýsi duch, jistě, ale je to jiné. Já sám bych samozřejmě dal za každého člena katedry ruku do ohně. Koneckonců jsem skoro všecky učil, takže to mohu takto říct.

$\mathrm{N}$ : Vy ted' mluvíte o vnitřní atmosféré té katedry, o čemž já nemohu vydávat žádné svědectví, protože na ní nežiji. Ale mně spís jde u té otázky o to, jakou funkci má ta katedra v rámci celé fakulty. A já ř́kám, že při dnešní roztř̌šstěnosti a rozdrobenosti fakulty hodně možností, jak toho ducha promítat do sousedních oborů, ubylo.

\section{Z: Ano, ubylo.}

N: Doufejme, že jak nás sestěhovali, tak je to možná přechodné.

P: Moc děkuji, že jste tak dlouho byli ochotni odpovídat.

N: Dlouho! Já vyjadřuji své potěšení nad tím, že jste mne pozvali, protože tak si ř́kám, jak já k tomu přijdu, nemajíc s filosofií v podstatě nic společného kromě těch historicky dobrých vztahů a kromě skutečného zájmu o věc, a takových by asi na té fakultě bylo mnohem víc. $V$ běhu mého fakultního života toto pozvání pro mne něco znamená. 